Rolle, F. 1985: Late Cretaceous-Tertiary sediments offshore central West Greenland: lithostratigraphy, sedimentary evolution, and petroleum potential. Can. J. Earth Sci. 22, 1001-1019.

Rosenkrantz, A. \& Pulvertaft, T. C. R. 1969: Cretaceous-Tertiary stratigraphy and tectonics in northern West Greenland. Mem. Am. Ass. Petrol. Geol. 12, 883-898.

Schiener, E. J. \& Leythaeuser, D. 1978: Petroleum potential off W. Greenland. Oil and Gas J. 76(40), 223-234.

Shekhar, S. C., Frandsen, N. \& Thomsen, E. 1982: Coal on Nûgssuaq, West Greenland. Unpubl. intern. GGU rep., 82 pp.

Institut for Almen Geologi,

$\emptyset$ ster Voldgade 10,

DK-1350 København K,

Denmark.

\title{
Geophysical investigations of the Qaqarssuk Carbonatite Complex, southern West Greenland
}

\author{
Morten Kjærgaard, Christian Knudsen and Niels Abrahamsen
}

During the summers of 1984 and 1985, geophysical investigations were made in the Qaqarssuk area, situated $65^{\circ} 23^{\prime} \mathrm{N}, 51^{\circ} 40^{\prime} \mathrm{W}$, in connection with exploration for phosphorus, niobium and lanthanide deposits of potential economic interest. The geophysical field work carried out in the summer of 1984 has previously been briefly discussed (Kjærgaard \& Olsen, 1985a). Most of the interpretations have now been completed, some of which are presented below, together with the new results from 1985.

The investigations focussed on three subjects:

(1) Shallow seismic and geoelectric measurements to map the thickness of residual soil (possibly enriched in $\mathrm{P}$ and $\mathrm{Nb}$ ) overlying the carbonatite.

(2) Radiometric measurements to localise pyrochlore-rich (U bearing) and lanthanide-rich carbonatites (Th bearing).

(3) Magnetic investigations, primarily to map the structures in the carbonatite.

A general description of the geology of the complex is given in Knudsen (1985) and Knudsen (1986). A geological sketch map is shown in fig. 1.

\section{Shallow seismic and geoelectric investigations of the overburden}

The interpretation of the seismic lines (Kjærgaard \& Olsen, 1985a, b) was made by computer, and the plus-minus method of interpreting seismic sections was used where possible. The DC geoelectric sounding curves were interpreted by an iterative computer programme at the Laboratory of Geophysics, Aarhus.

In most places the interpretation of the seismic and geoelectric measurements gives consist- 

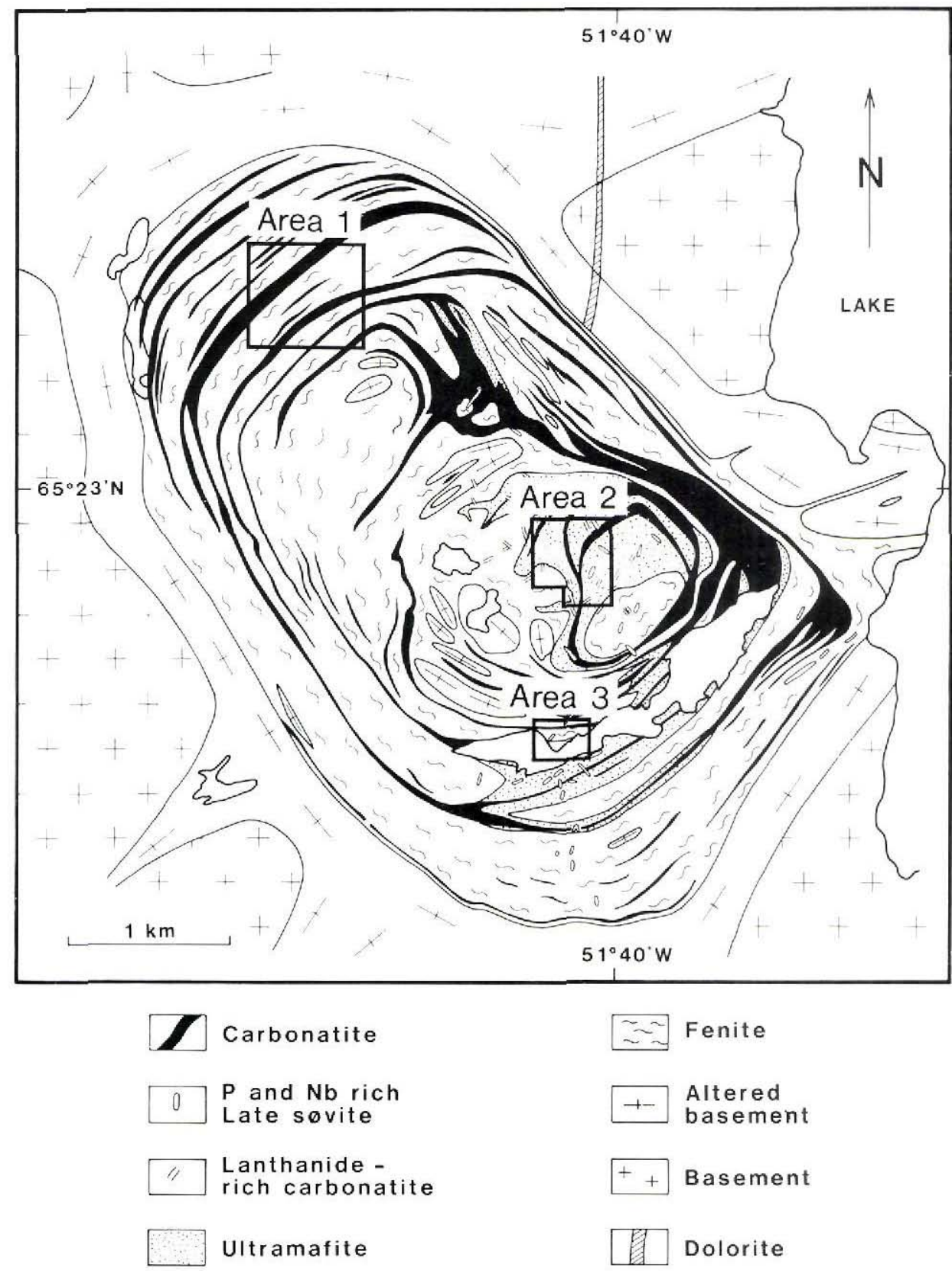

Fig. 1. Geological sketch map of the Qaqarssuk carbonatite complex, West Greenland (from Knudsen, 1985). 


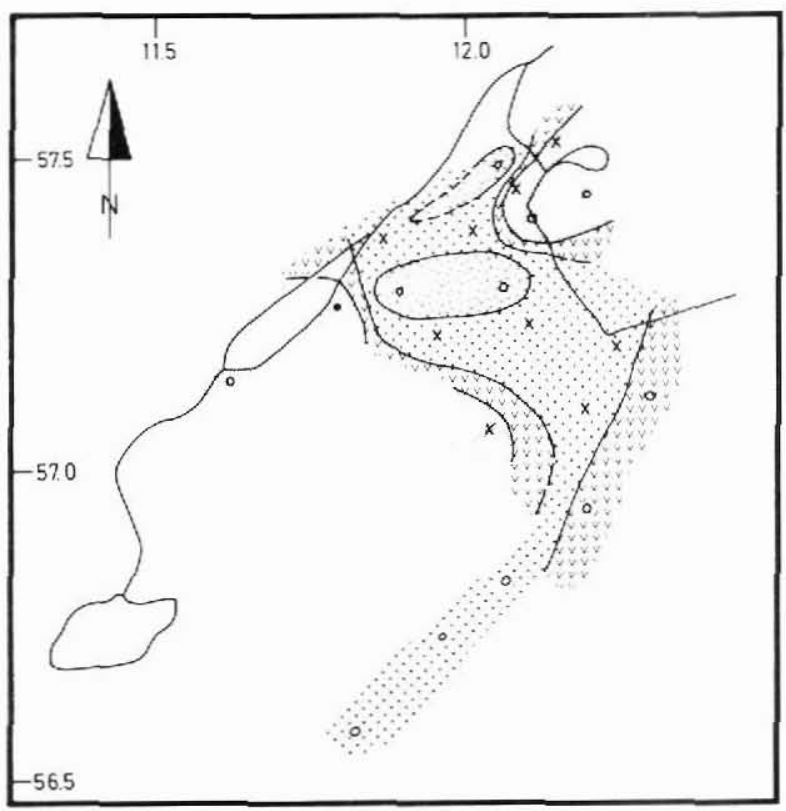

Fig. 2. Isopach map showing variation in thickness of the overburden in an area of the northern part of the carbonatite complex based on scismic and geoclectric measurements. The coordinates refer to the local coordinate system.

x Seismic measurement point

- Geoelectric measurement point
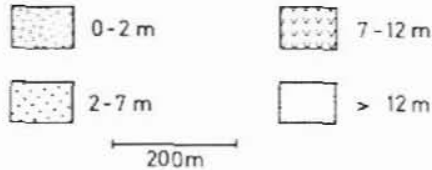

ent results on the thickness of the overburden layers, and it was often possible to assign a resistivity and velocity to the different layers. The deduced thickness also fits well with the drill hole investigations made by the Kryolitselskabet Øresund A/S. On the basis of the deduced thicknesses it was possible to construct isopach maps of the overburden (Kjærgaard \& OIsen, 1985b), one of which is shown in fig. 2. An average overburden of $5 \mathrm{~m}$ was earlier deduced from drill holes (Knudsen \& Secher, 1984). The present interpretation shows that the thickness of the overburden varies from $1 \mathrm{~m}$ to over $20 \mathrm{~m}$.

It is, however, not the total overburden but only the regolith part which is of potential economic interest, and the regolith can only be properly detected in a few places (and only by the geoelectric method). Therefore, it was not possible to construct a regolith isopach map. In places where the regolith can be detected, the thickness varies from 1.5 to $>20 \mathrm{~m}$. The thickness of the fluvial sediments and soil was never found to exceed $14 \mathrm{~m}$.

It seems likely that ice lenses, which have never been seen in the drill hole investigations (Leijo Keto, Kryolitselskabet Øresund A/S, personal communication), are present in all the investigated areas. This complicates the interpretation because the velocity of sound in ice is almost the same $(3500 \mathrm{~m} / \mathrm{s})$ as the velocity in hard rock, and because the resistivity of ice could be the same ( $>7500 \Omega \mathrm{m}$ ) as the resistivity of a hard-rock layer. In three places the presence of ice lenses was confirmed by direct observation in control pits.

\section{Radiometric investigations}

Radiometric investigations carried out in the Qaqarssuk area by the Kryolitselskabet $\emptyset$ resund A/S in 1970 and 1971 (Kurki et al., 1972), indicated that the highest concentrations of radioactive elements are located in the margin of the complex. The radiometric investi- 

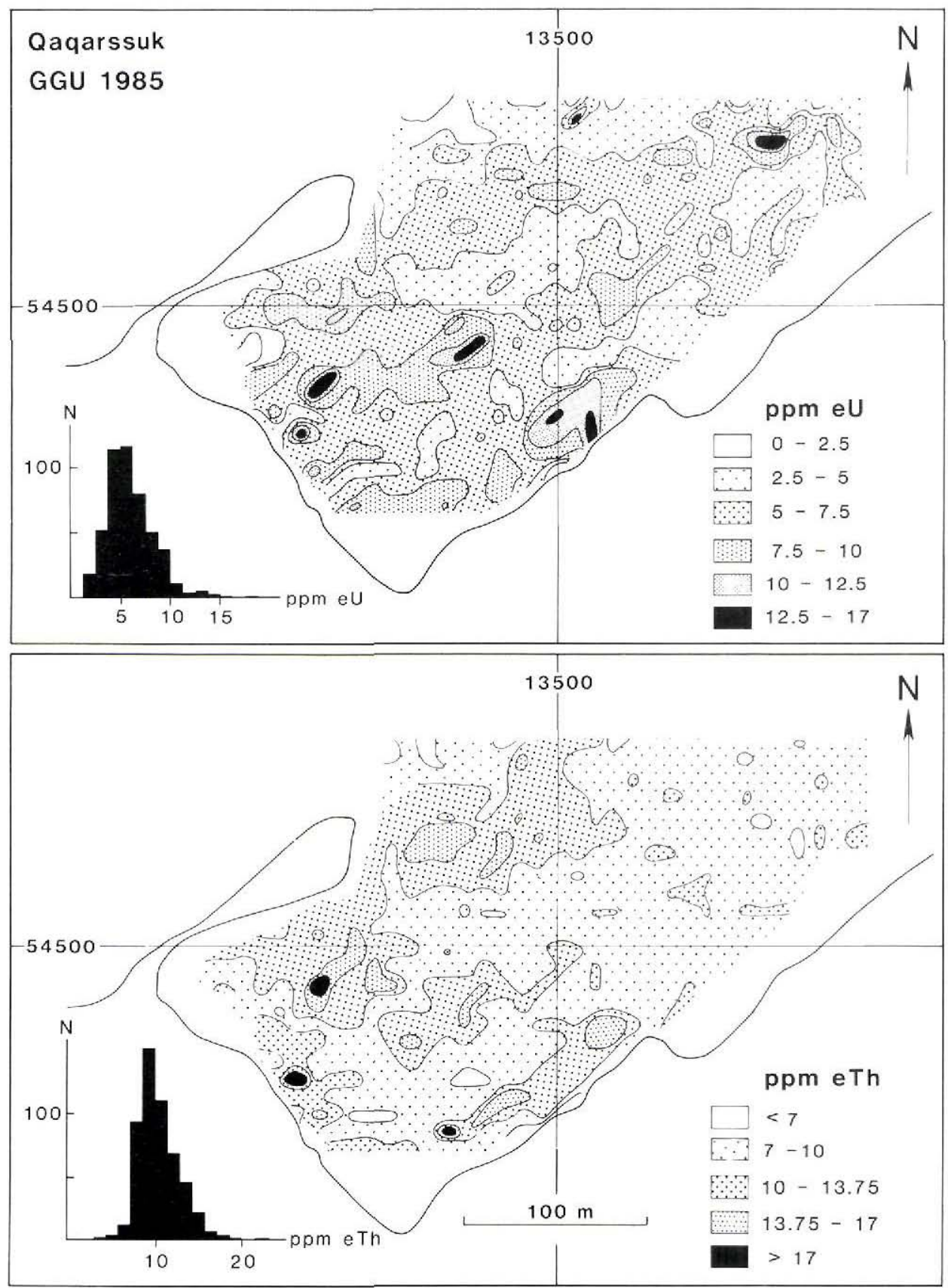

Fig. 3. Radiometric maps of area 3 (fig.1). The eU and $\mathrm{eTh}$ concentrations are calculated from measurements carried out by a portable, four channel gamma-ray spectrometer. Profile lines are orientated $\mathrm{E}-\mathrm{W}$, the sample interval is $10 \times 10 \mathrm{~m}$ and the coordinates refer to a local coordinate system. 
gations were used as a guide for a drilling programme for lanthanide-rich rocks, but no economic accumulations were found. A radiometric survey carried out by Ris $\varnothing$ in 1977 (Kunzendorf \& Sørensen, 1982) located several radioactive zones, but the source of the radiation was not identified.

During field work carried out in 1984 (Knudsen, 1985) and subsequent laboratory work, it was found that the Th/lanthanide ratio is lower in the core than in the rim of the complex, and that the most lanthanide-rich rocks are found in the core of the complex. The pyrochlore is uranium bearing, the tantalum content can be correlated with the uranium content, and it is possible to trace the pyrochlore with a scintilometer.

In 1985 a four channel gamma-ray spectrometer survey was carried out in two areas in the central part of the complex. The radiometric investigations were made with a Geometrics GR 410 four channel gamma-ray spectrometer (channels: total, K, U, Th). The instrument was backpacked $1 \mathrm{~m}$ above ground. Counting time was 2 minutes. Background radiation was measured twice a day over $2 \mathrm{~m}$ of water. The instrument was calibrated on concrete pads at Risø.

Area 2 (fig. 1) was chosen where lanthanide-rich carbonatite was known to be abundant in outcrops. A sample interval of 25 by $25 \mathrm{~m}$ was chosen. Area 3 (fig. 1) was chosen where soil samples collected in 1984 indicate the presence of $\mathrm{Nb}$ and lanthanide-rich rocks in the bedrock. The bedrock is covered by 0.2 to $1 \mathrm{~m}$ soil, and only very few outcrops are seen in the area. A sample interval of 10 by $10 \mathrm{~m}$ was chosen.

The survey in area 2 showed that the sample interval was too low to pick up all lanthaniderich carbonatites seen in outcrops. However, the anomaly pattern shows the NE-SW and NW-SE trend of the major lanthanide-rich carbonatites in the area. The boundary between fenite and carbonatite-ultramafite can be followed on the radiometric map because the background radiation (Th and $U$ ) on the fenite is approximately 1.5 times higher than on the ultramafites and common carbonatites.

The survey in area 3 (fig. 3) showed that the geochemical anomalies coincide with radiometric anomalies, and that both the eU and eTh anomalies follow a NE-SW trend. The source of the geochemical and radiometric anomalies was confirmed by digging to be lanthanide-rich and late calcite dominated carbonatite. The fact that the eU and $\mathrm{eTh}$ anomalies often are located on strike indicates that the Th - lanthanide-rich carbonatites and the $\mathrm{U}$ pyrochlore bearing carbonatites often are located along the same fractures or veins.

\section{Magnetic investigation of the bedrock}

Susceptibility measurements. Susceptibility measurements in the present study were carried out with a hand-held kappameter (Geofyzika Brno, kT-5) ranging between $10^{-5}$ and $1 \mathrm{SI}$ units, on 320 samples collected from the area. The distribution of susceptibility (fig. 4) in any rock type is usually log-normal (Tarling, 1971; Henkel, 1980), and this suggests that the main influence on both susceptibility and intensity of remanence within any rock type may be the distribution of grain size as these are log-normally distributed (Tarling, 1971). But in the present case - even in a logarithmic plot - all the distributions are skew to the right, i.e. with a peak at low values tailing off towards high values.

The susceptibility distributions of the altered and little-altered basement, the fenite (metasomatically altered basement in which no quartz has survived), the carbonatite and the ultra- 

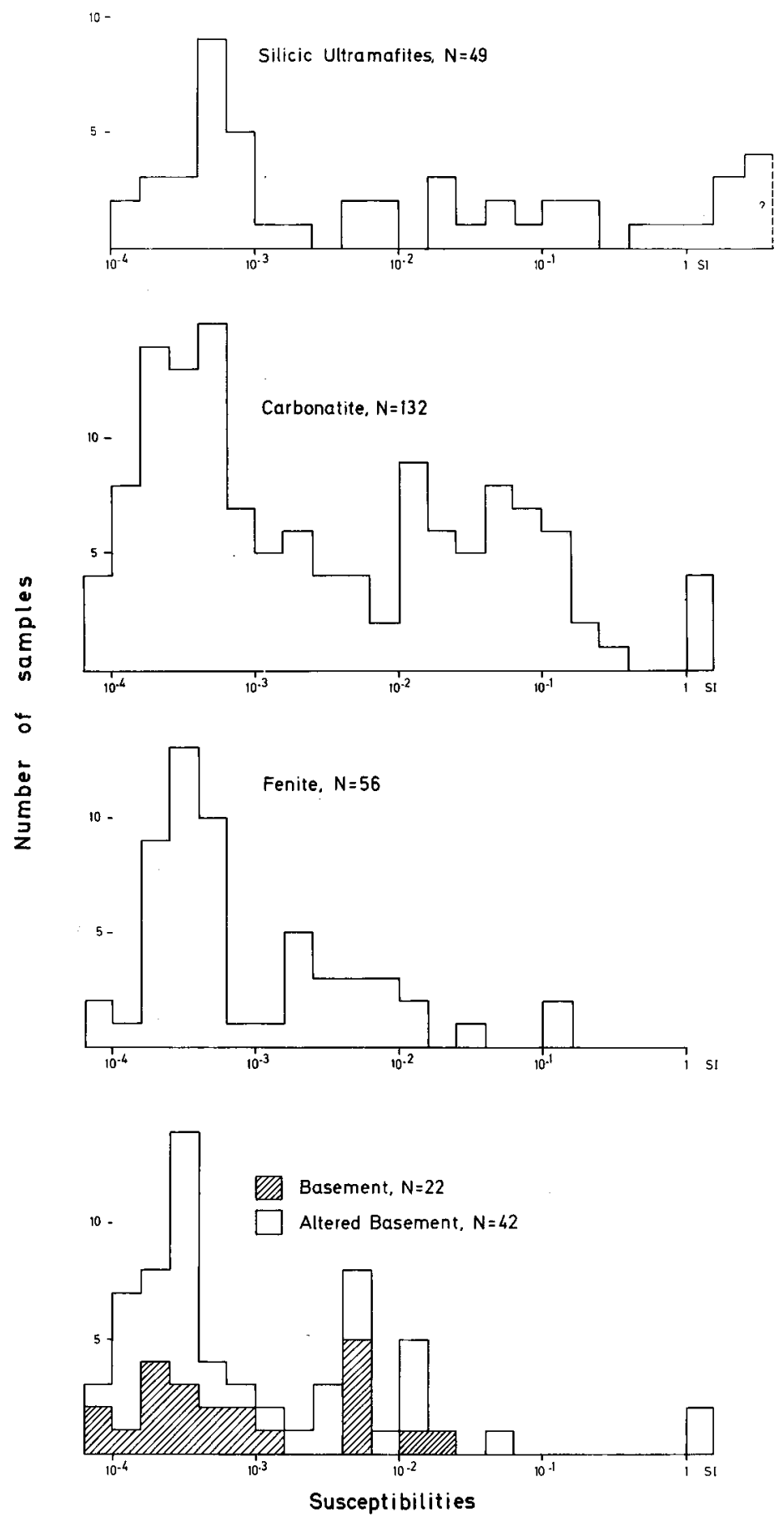

Fig. 4. Histograms showing the skew log-normal distributions of susceptibility measurements for the four major rock types (logarithmic scale). 
mafite are shown in fig. 4. From the basement to the ultramafites the distribution differs more and more from a log-normal distribution and the scattering of the susceptibility values increases. Also the mean value of susceptibilities increases in this sequence.

The histogram of the susceptibilities of basement rock samples shows a slight tendency towards two peaks. The mean value is a little less than $10^{-3} \mathrm{SI}$ units corresponding to results from e.g. Archaean gneisses from central North Greenland (Abrahamsen \& Van der Voo, 1987), which give values from $5 \times 10^{-4}$ to $10^{-2}$ and a mean value of about $10^{-3} \mathrm{SI}$ units.

The histograms of fenites are almost similar. Here there are values within the range $10^{-4}$ to $10^{-1} \mathrm{SI}$ units and a tendency for two peaks. The mean value is about $10^{-3} \mathrm{SI}$ units. Investigations from the Fen carbonatite complex in Norway give intensities of the NRM from $10^{-5}$ to $10^{-4}$ gauss and Qn values from 1 to 10 (Poorter, 1972). This corresponds to a susceptibility of the order of $10^{-3}$ to $10^{-5} \mathrm{SI}$ units or about one or two orders of magnitude lower.

In the carbonatite histogram we clearly have two clusterings. One with susceptibilities ranging between $10^{-4}$ and $10^{-2} \mathrm{SI}$ units, having a mean value of $5 \times 10^{-4} \mathrm{SI}$ units, and another cluster with susceptibilities ranging between $10^{-2}$ and $1 \mathrm{SI}$ units, having a mean value of about $10^{-1} \mathrm{SI}$ units. The peak between $10^{-4}$ and $10^{-2} \mathrm{SI}$ units corresponds to the low-valued peaks in the fenite and the basement. The high values of susceptibilities (about 1 SI unit) are due to the very high magnetite content in some of the carbonatite sheets (the søvites).

In the histogram of ultramafites the values cover a range of approximately 5 orders of magnitude. There is a peak in the usual interval of $10^{-4}$ to $10^{-3} \mathrm{SI}$ units, but the rest of the values scatter over the whole histogram from $10^{-4}$ to more than 2 SI units (overflow on the kappameter). The high values are caused by a very high magnetite content in samples consisting of almost pure magnetite.

Measurements of the magnetic field. The mapping of structures in the bedrock is based on measurements carried out by the Kryolitselskabet Øresund A/S (Kurki et al., 1972; Gothenborg \& Pedersen, 1976). The data consist of two parts; measurements of the vertical magnetic field in 1970-71, and measurements of the total magnetic field in 1975.

Measurements of the vertical magnetic field were carried out with three Ascania magnetometers. The survey covered most of the carbonatite complex, and the measurements were made in a $50 \times 50 \mathrm{~m}$ grid in a local coordinate system established for the purpose. In all, 9743 points were measured. The data were given as instrument values and it was necessary to convert the readings to residual anomaly values by multiplying with a correction factor specific for each instrument. It was further necessary to correct each set of data for the zero level and for the magnetic drift. The correction for drift was made by remeasuring a reference point. The residual values of the vertical magnetic field vary between $-2215 \mathrm{nT}$ and $+30838 \mathrm{nT}$ and showed fairly large anomalies within short distances (up to $29400 \mathrm{nT}$ within $25 \mathrm{~m})$.

The total magnetic field was measured in a $10 \times 25 \mathrm{~m}$ grid in the south-eastern corner of the complex. The measurements were carried out with a scintrex MP-2 proton precession magnetometer which measures the total component of the flux density of the geomagnetic field with a reading accuracy of $1 \mathrm{nT}$. The grid almost covers the dominating inner core of the complex. The grid area covered $2.5 \mathrm{~km}^{2}$ and 9788 grid points were measured. No correction of the data was made as it was unnecessary to eliminate the daily variation of the geomagnetic field (Mikkola, 1976). The values of the total magnetic field vary between 53244 $\mathrm{nT}$ and $79967 \mathrm{nT}$ and very strong local anomalies were found within a distance of $10 \mathrm{~m}$ (up to $21300 \mathrm{nT})$. 


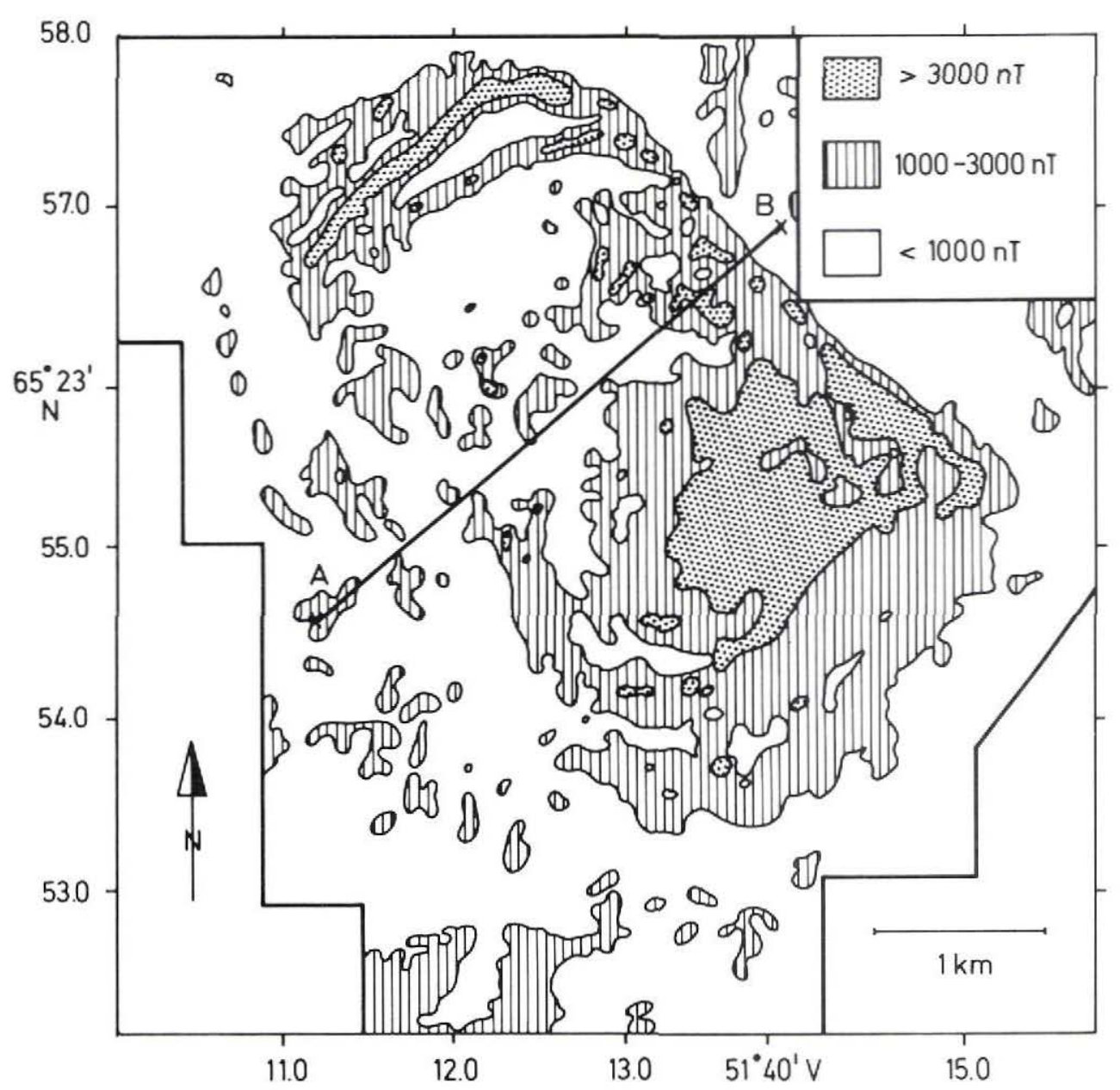

Fig. 5. The vertical magnetic residual field of the complex. The line AB refers to the cross section - fig. 6. The coordinates refer to the local coordinate system.

Interpretation of the magnetic field. Various contour maps have been constructed by means of computer systems at the Laboratory of Geophysics in Aarhus and at The Geological Survey of Greenland (Thorning, 1982). Several different filtering techniques were applied in the processing of the data for the maps and to derive a depth synthesis from the data.

Two types of contour maps were constructed; a vertical magnetic field map covering the total area (fig. 5), and a more detailed total magnetic field map covering only the southeastern corner with the dominating inner core of the complex.

The most striking features on these maps are marked, semi-rectangular, ring-shaped or curved anomalies. These may be correlated with the occurrence of major steeply dipping s $\varnothing-$ 
vite sheets. The strong magnetic anomalies are caused by the high magnetite content (sometimes almost pure magnetite accumulations) in the søvites and associated glimmerites, while the rauhaugite, the silico-søvite and the ultramafites are associated with weak magnetic anomalies.

Another feature is the subcircular positive anomaly in the south-eastern part of the core of the complex. This can be ascribed to the high frequency of both $s ø$ vite and glimmerite rich in magnetite in this area. The positive anomaly covers a larger area than the carbonatite itself, confirming that the søvites and associated rocks are cone-shaped with outward dipping sides.

The core in the south-eastern part of the complex is surrounded by a number of concentric, positive anomalies which are more or less continuous and which may be correlated with søvite ring dykes around the core.

Anomalies in the north-western area of the inner part of the complex support geological observations indicating the presence of a minor cone-shaped set of carbonatite dykes - and hence another inner core (Knudsen, 1986). A suite of magnetic anomalies in the southern part of the complex may be correlated with late søvite containing accumulations of magnetite and of magnetite-apatite-pyrochlore.

The whole complex is surrounded by a negative magnetic anomaly which is likely to be caused by the high degree of hydrothermal alteration of the basement in which the magnetite has been altered to hematite. This anomaly coincides with the radiometric anomaly surrounding the complex caused by thorium enrichment (Kurki et al., 1972).

The radiating carbonatite veins and shear zones are only recognised on the magnetic map in the south-eastern part of the complex, where two anomalies radiating from the complex may be correlated with carbonatite veins. An approximately $15 \mathrm{~m}$ wide, $\mathrm{N}-\mathrm{S}$ trending dolerite dyke, cut by the rocks of the carbonatite complex, is clearly seen on the magnetic map in the north-eastern part, the possible continuation of the dyke south of the complex is more debatable.

A negative magnetic anomaly cutting the structure of the carbonatite in the western part of the complex coincides with a steep valley and is probably a topographic effect.

On the contour maps the eastern margin of the complex is better defined than the western margin. This is explained, partly by the higher frequency of carbonatite sheets along the eastern margin, partly by the carbonatite sheets having a higher magnetite content, and partly by the less frequent overburden of the eastern margin compared to the western.

The fact that the eastern margin is well defined relative to the western margin can also be seen on the magnetic profile (fig. 6). At the eastern margin two strong positive anomalies are seen, which can be correlated with the two major steeply dipping søvite sheets. In the western margin the anomalies from the søvite sheets are not so obvious. In the central part of the complex some fluctuations due to the banding of the structure are also seen.

\section{Conclusions}

The use of a geoelectric survey method provided more reliable information about the overburden than the seismic survey in this area. It was possible to map the total thickness of the overburden and to localise deposits of residual soil overlying the carbonatite. The geoelectric method may also give a rough determination of the character of the bedrock beneath the overburden. 


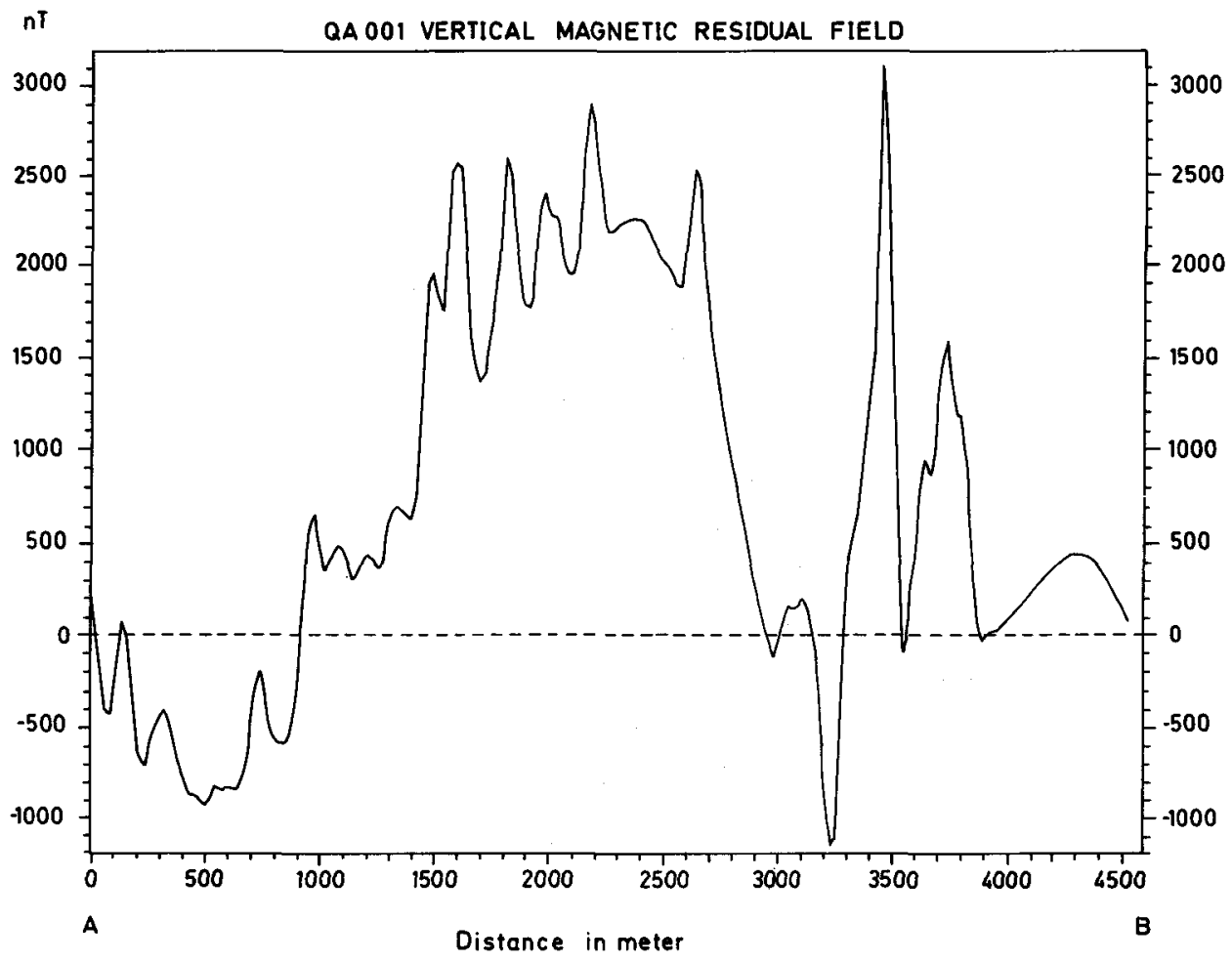

Fig. 6. Cross section of the vertical magnetic residual field from south-west (A) to north-east (B). The line $A B$ is shown in fig. 5.

The gamma-ray spectrometer proved to be a very useful tool for mapping and exploration of the carbonatite. It showed that $\mathrm{Th}$ and $\mathrm{U}$ radiation levels are higher over fenite than over unmineralised ultramafite and carbonatite, that pyrochlore-rich carbonatites could be localised on their high eU/eTh values, increasing with increasing Ta content in the pyrochlore, and that lanthanide-rich carbonatites in the core of the complex were localised on their high $\mathrm{eTh} / \mathrm{eU}$. The radiometric investigations indicate that the pyrochlore-rich and the lanthaniderich carbonatites are located on strike and probably deposited at different locations/facies in the same fractures or veins.

The magnetic picture of the carbonatite complex revealed many trends and details which were useful in the geological mapping of the area. Although the sample distance is too high to clearly distinguish all the carbonatite sheets, it was possible to follow many structures from exposure to exposure on the magnetic maps. In areas covered by overburden the magnetic pattern is the main basis for the geological mapping, and detailed magnetic investigations are highly recommended as mapping and exploration tools in carbonatites and similar deposits. 
Acknowledgements. The field work in 1984 was carried out together with K. B. Olsen and in 1985 together with Trine Boiesen. The magnetic data were provided by the Kryolitselskabet Øresund A/S. L. Thorning and M. Svane, GGU, provided facilities and assistance in the magnetic processing, and B. H. Jacobsen supervised M. K. The field work was supported by the European Economic Community through contract number MSM $119 \mathrm{DK}(\mathrm{G})$.

\section{References}

Abrahamsen, N. \& Van der Voo, R. 1987: Magnetic susceptibility and palaeomagnetic collection of rocks from central and western North Greenland. Rapp. Gronlands geol. Unders. 133, 133-140.

Gothenborg, J. \& Pedersen, J. L. 1976: Exploration of the Qaqarssuk Carbonatite Complex, 1975, part II. Kryolitselskabet Øresund A/S. Unpubl. company rep.

Henkel, H. 1980: Petrophysical properties (density, magnetic susceptibility and natural remanent magnetisation) of rocks in Sweden. Geof. Rapp. Sveriges geol. Unders. 8013, 33 pp.

Kjærgaard, M. \& Olsen, K. B. 1985a: Shallow-seismic, geoelectric and magnetic investigation of the Qaqarssuk Carbonatite Complex, West Greenland. Rapp. Grónlands geol. Unders. 125, 40-44.

Kjærgaard, M. \& Olsen, K. B. 1985b: Geoelectric and seismic investigations at Qaqarssuk. Lab. of Geophysics, University of Aarhus. Unpubl. rep. (in Danish), 64 pp.

Knudsen, C. 1985: Investigation of the Qaqarssuk Carbonatite Complex, southern West Greenland. Rapp. Gronlands geol. Unders. 125, 34-40.

Knudsen, C. 1986: Apatite mineralisations in carbonatite and ultramafic intrusions in Greenland. Final rep. from GGU, $176 \mathrm{pp}$.

Knudsen, C. \& Secher, K. 1984: Apatite mineralisation in carbonatite and ultramafic intrusions in Greenland. Unpubl. intern. GGU rep., 24 pp.

Kunzendorf, H. \& Sørensen, P. 1982: Reconnaissance geochemical sampling in the Qaqarssuk Carbonatite Complex, West Greenland. Risø. unpubl. intern. rep., 51 pp.

Kurki, J., Juhava, R. \& Gothenborg, J. 1972: Report on the exploration in Søndre Isortoq area, 1971. Kryolitselskabet Øresund A/S. Unpubl. company rep.

Mikkola, P. 1976: Report of the magnetic survey in Qaqarssuk, Western Greenland, in the summer 1975. Suomen Malmi OY. Unpubl. company rep., 3 pp.

Poorter R. E. P. 1972: Preliminary paleomagnetic results from the Fen Carbonatite Complex, S. Norway. Earth planet. Sci. Lett. 17, 194-198.

Tarling, O. H. 1971: Principles and applications of paleomagnetism. Chapmann and Hall, $164 \mathrm{pp}$.

Thorning, L. 1982: Processing and interpretation of aeromagnetic data in The Geological Survey of Greenland. Rapp. Grønlands geol. Unders. 114, 42 pp.

M. $K \& N . A$., Laboratoriet for Geofysik, Aarhus Universitet, Finlandsgade 6-8, DK-8200 Ärhus N, Denmark. 